\title{
Prosodic Word and Morphological Derivation in Brazilian Portuguese
}

\author{
Luiz Carlos Schwindt \\ Universidade Federal do Rio Grande do Sul, Brazil
}

\section{Introduction}

In this paper, I discuss the prosodic status of words formed by morphological derivation in Brazilian Portuguese (BP). From the description of types of prosodization of prefixed and suffixed words in BP, I seek to problematize some consequences of this typology for the organization of the prosodic hierarchy and its effects on morphological transparency.

According to Schwindt (2000), Bisol (2004), and others, prosodic words (PW) can be equal, smaller or larger than morphosyntactic words (MW) in BP.

(1) Domains of prosodic words in BP
a. $\mathrm{PW}=\mathrm{MW}$
casa $]_{\mathrm{PW}, \mathrm{MW}}$
home
pre-carnival
isolated word
b. $\mathrm{PW}<\mathrm{MW}$
pre $]_{\mathrm{PW}}$ carnaval $\left.]_{\mathrm{PW}}\right]_{\mathrm{MW}}$
small coffee
cafe $\left.\left.]_{\mathrm{PW}} \mathrm{zinho}\right]_{\mathrm{PW}}\right]_{\mathrm{MW}}$
cachorro $]_{\mathrm{PW}}$ quente $\left.]_{\mathrm{PW}}\right]_{\mathrm{MW}}$
hotdog
c. $\mathrm{PW}>\mathrm{MW} \quad \mathrm{me}]_{\mathrm{MW}}$ espere $\left.]_{\mathrm{MW}}\right]_{\mathrm{PW}}$
wait for me
prefixed word
suffixed word
compound
clitic

Words derived morphologically may show the first two domains, depending on if affixes are related to their bases in a structure of prosodic composition, adjunction or incorporation (Booij, 1996; Ito \& Mester, 2008; Vigário, 2011).

(2) Prosodic sites for affixes in BP

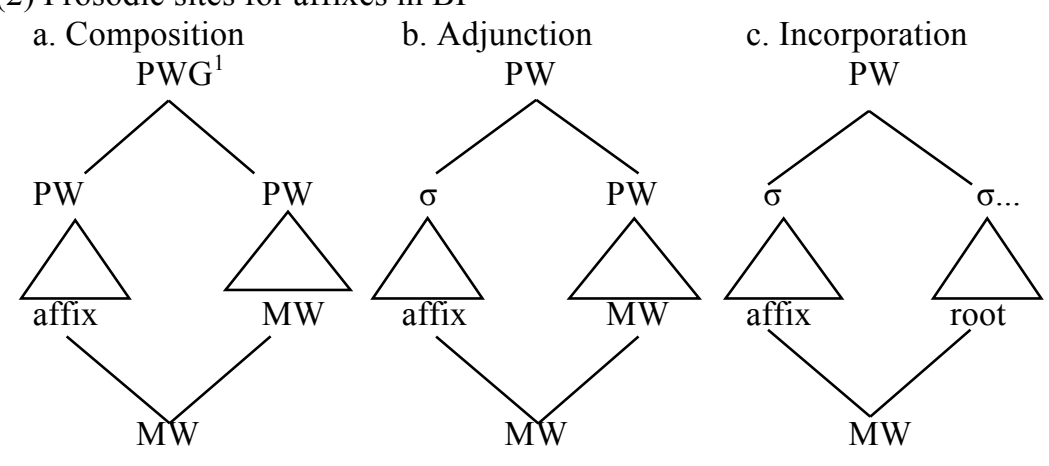

In (2a), an affix that is primarily stressed and constitutes an independent PW is added to a well-formed $\mathrm{PW}$ in a structure of composition. There is no consensus about the superordinate category in this case: if a recursive prosodic word, a clitic group, a phonological phrase or a prosodic word group (Schwindt, 2000; Nespor and Vogel, 1986; Vigário, 2011, among others). In (2b), the affix, as an unstressed structure, is added to a well-formed PW. However, the affix per se does not behave as a PW in this case. This

\footnotetext{
* For comments and suggestions on prior presentations of the ideas in this paper, I thank Gisela Collischonn and Michael Becker, though none of them should be held responsible for any potential errors. I also thank Coordenação de Aperfeiçoamento de Pessoal de Nível Superior (CAPES) and Conselho Nacional de Desenvolvimento Científico e Tecnológico $(\mathrm{CNPq})$ for financial support to this research.

${ }^{1}$ Since I defend that there is no stress reassignment in prosodic composition, I am assuming tentatively the category "Prosodic Word Group", proposed by Vigário (2011), instead of the analysis of recursive prosodic words.
} 
configuration requires admitting recursion of PW. In (2c), an unstressed affix is added to a root and forms with it a single PW.

\section{Proposal}

In this analysis we propose that Brazilian Portuguese prefixes are subject to the three types of prosodization described above, whereas suffixes are subject only to composition and incorporation, not to adjunction. This is exemplified in (3) and (4).

(3) Prosodization of prefixes in BP
a. Composition
b. Adjunction
c. Incorporation
$\left[\left[\mathrm{PW}_{\mathrm{AFFIX}}\right]+\left[\mathrm{PW}_{\mathrm{MW}}\right]\right] \mathrm{PWG}_{\mathrm{MW}}$
$\left[\sigma_{\mathrm{AFFIX}}+[\sigma \ldots] \mathrm{PW}_{\mathrm{MW}}\right] \mathrm{PW}_{\mathrm{MW}}$
pré-carnaval pre-carnival
inescrito unwritten
$\left[\sigma_{\text {AFFIX }}+\sigma_{\ldots \text { ROOT }}\right] \mathrm{PW}_{\mathrm{MW}}$
inscrito registered

(4) Prosodization of sufixes in BP
a. Composition
b. Adjunction
c. Incorporation
$\left.\left[[\mathrm{PW}]_{\mathrm{MW}}+[\mathrm{PW}]_{\mathrm{AFFIX}}\right] \mathrm{PWG}_{\mathrm{MW}} *\left[[\sigma \ldots] \mathrm{PW}_{\mathrm{MW}}+\sigma_{\mathrm{AFFIX}}\right]\right] \mathrm{PW}_{\mathrm{MW}}$
cafezinho small coffe
$\left[\sigma \ldots\right.$ ROOT $\left.^{+} \sigma(\sigma)_{\text {AFFIX }}\right] \mathrm{PW}_{\mathrm{MW}}$
brevidade brevity

2.1 Evidences The main argument to support the classification proposed above comes from the diagnostic of stress assignment. In addition, I examine other phonological processes that occur within words in contrast to processes that occur at word boundaries, as well as the morphosyntactic behavior of the affixes involved. According to these criteria, the analytical proposal can be summarized as follows.

Composition Prefixes and suffixes in BP can be stressed. The main evidence is the non-application of the process that raises lower-mid vowels in pretonic syllables in some prefixed and suffixed words. In addition, these affixes show some syntactic-semantic autonomy.

Adjunction In certain prefixed words, the left edge of the base is subject to the same processes that simple words undergo. However, the affix per se does not behave as a PW in this case.

Incorporation Certain prefixed and suffixed words are subject to the same phonological processes that apply within non-complex words.

\subsubsection{Evidences for prosodic composition}

2.1.1.1 Stress Compositional affixes follow the general pattern of stress in BP (which includes monosyllabic words besides trochees).

Neutralization of pretonic vowel In BP, the opposition between upper and lower-mid vowels is neutralized outside the stress position within the limits of PW. As a consequence, in many dialects, lower-mid vowels are restricted to stressed syllables. This process does not apply, however, with certain affixes.

(5) Affixes and neutralization of pretonic vowel in BP

$$
\text { Non-compositional affixes Compositional affixes }
$$

prefixed words a. $\mathrm{p}[\mathrm{o}] \mathrm{sp}[\mathrm{o}]$ sto postponed $\quad$ c. pr[ć]-carnav[á]l pre-carnival
suffixed words
b. $\mathrm{m}[\mathrm{e}] \mathrm{dic}[1$ ] na medicine
d. b[ó]l[1́]nha
little ball

According the widespread idea that prosodic words must bear one and only one primary (word) stress, the affixes in (5c) and (5d) are considered independent PWs. This can be confirmed by the presence of lower-mid vowels in positions presumably unstressed of these words.

2.1.1.2 Syntactic-semantic Autonomy Besides the stress, compositional affixes in BP usually show some syntactic-semantic independence.

(i) They can be suppressed when preceded or followed by words with identical affixes.

(6) a. Este é um efeito pós-guerra e crise (crise = pós-crise).

This is an effect of post-war and post-crisis. 
b. *Maria recalculou os custos e enviou os convites. (= reenviou os convites)

Mary recalculated the costs and remanded the invitations.

(7) a. Ela perdeu peso rápida e seguramente. (rápida = rapidamente)

She lost weight quickly and safetly.

b. *Era uma relação de bom e cumplicidade. (bom = bondade)

It was a relationship of kindness and complicity.

(ii) They can instantiate isolatedly in a sentence (depending on some referent).

(8) a. A cirurgia foi bem, mas ela está sofrendo no pós. (pós=pós-operatório)

The surgery went well, but she is suffering in postoperative.

b. *João desfez suas malas e Maria re as delas. $(\mathrm{re}=$ refez $)$

John unpacked his bag and Mary repacked hers.

(9) a. Era só um zinho falando. (zinho = algunzinho, pessoazinha)

It was just an unimportant person talking.

b. *O primeiro prato era ruim, mas este é realmente oso (oso = gostoso)

The first dish was bad, but this is really tasty.

2.1.2 Evidences for prosodic adjunction: $P W$-boundary processes Adjoined prefixes undergo neither processes that apply at the right edge of prosodic words nor juncture processes. However, left edge processes can affect their bases.

(10) Adjoined prefixes and PW-boundary processes

$\begin{array}{ll}\text { prefixed structure } & \text { phrase structure } \\ \text { re+exame } & \text { este exame } \\ \text { re-examination } & \text { this examination } \\ { }^{*} \text { r[i]exame } & \text { est }[\mathrm{i}] \text { exame } \\ { }^{*} \text { r[i]xame } & \text { est[i]xame } \\ \text { re[i]xame } & \text { este [i]xame } \\ \text { re+socializar } & \text { esta sociedade } \\ \text { re-socialize } & \text { this society } \\ \text { re[s]ocializar } & \text { esta [s]ociedade }\end{array}$

a. final raising

b. degemination

c. initial raising

d. initial voicing identity

re[s]ocializar

Unlike, most of suffixed words do not show evidences of PW internal edges, suggesting incorporation instead of adjunction.

(11) Incorporated suffixes and PW-boundary processes

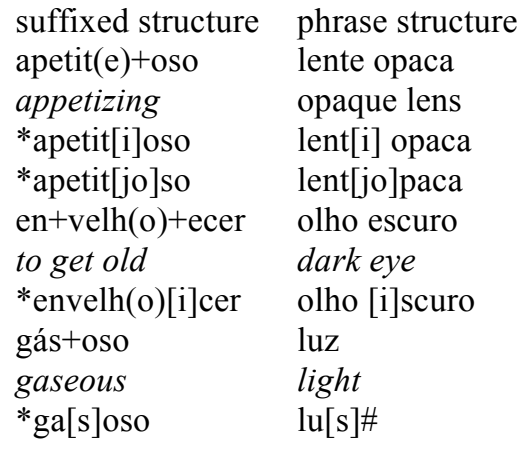

a. final raising *apetit[i]oso lent[i] opaca

b. diphthongization *apetit[jo]so lent[jo]paca

en+velh(o)+ecer olho escuro

c. initial raising $\quad *$ envelh(o)[i]cer olho [i]scuro

$\begin{array}{ll}\text { gás+oso } & \text { luz } \\ \text { gaseous } & \text { light }\end{array}$

d. final $[\mathrm{s}] \quad$ *ga[s]oso $\quad \mathrm{lu}[\mathrm{s}] \#$

2.1.3 Evidences for prosodic incorporation: Epenthesis Like other Romance languages, BP has roots initiated by $/ \mathrm{sC} /$ (Collischonn and Schwindt, 2005). This syllabic structure, however, is commonly repaired by epenthesis. Prefixes may be added to the base before or after epenthesis, which permit us to distinguish between incorporation and adjunction. 
(12) Epenthesis as an evidence for incorporated/adjoined prefixes in BP
a. in $+[\text { scrito }]_{\text {ROOT }}$
inscrito
registered
b. in $+\left[\mathrm{e}+{ }_{\text {scrito }}\right]_{\mathrm{PW}, \mathrm{MW}}$
inescrito
unwritten
c. des $+[\text { struído }]_{\text {ROOT }}$
destruído
destroyed
d. des $+[\mathrm{e}+\text { struturado }]_{\mathrm{PW}, \mathrm{MW}}$
desestruturado
unstructured

Suffixed words in BP are typically root-based, and vowels that stand after roots are commonly part of the suffixes, since their shape does not necessarily coincide with the final vowel of the non-derived word.

(13) Vowel-initial suffixes and vowel-final words in BP

$\begin{array}{lllllll} & \text {-al } & & \text {-ice } & & \text {-oso } & \\ \text {-o } & \text { a. can }+ \text { al } & \text { canal } & \text { d. velh }+ \text { ice } & \text { old age } & \text { g. carinh+oso } & \text { affectionate } \\ \text {-a } & \text { b. pen }+ \text { al } & \text { penal } & \text { e. crianc+ice } & \text { childishness } & \text { h. esponj+oso } & \text { spongy } \\ \text {-e } & \text { c. dent+al } & \text { dental } & \text { f. foguet+ice } & \text { mischief } & \text { i. apetit+oso } & \text { appetizing }\end{array}$

Additional data contribute to put in doubt the hypothesis of vowel syncope before suffixation as a strategy to satisfy a CV template or avoid hiatus, contrary to what suggested by Bermúdez-Otero (2007) for Spanish.

(14) Hiatus and epenthesis in BP suffixed words

\begin{tabular}{|c|c|c|c|c|}
\hline \multicolumn{2}{|c|}{ simple word } & & no epenthesis \\
\hline & & & her & ina \\
\hline asco & $\begin{array}{l}\text { name of a soccer team } \\
\text { boat }\end{array}$ & & $\begin{array}{l}\text { Vasco's fan } \\
\text { boatman }\end{array}$ & 'ino \\
\hline
\end{tabular}

Vowels intervening between root and suffix represent a pattern quite exceptional in BP, generally corresponding to fossilized formations. Even in these cases, however, the epenthetic vowel does not necessarily agree with the final vowel of the correspondent simple word (e.g. preço $>$ precioso / * preçuoso price $>$ precious $)$.

\section{Discussion}

Two questions arise from the classification assumed here: (i) what are the consequences of this analysis for the organization of prosodic hierarchy? and (ii) what these structures may say about morphological transparency? Although these issues do not constitute the primary goal of this paper, I present below a summary table of initial insights on these problems. In this discussion, I assume two basic premises: generalized alignment constraints may account for the three types of prosodic constituency considered in the analysis, and coincidence between prosodic and morphological boundaries indicates greater semantic transparency of the morphemes involved.

\begin{tabular}{|c|c|}
\hline PROSODIC HIERARCHY & MORPHOLOGICAL EFFECTS \\
\hline \multicolumn{2}{|l|}{ COMPOSITION } \\
\hline $\begin{array}{l}\text { ALIGN (STRESS; PW), ALIGN (LEX;PW) } \\
\text { - affixes are PWs, since they are stressed and considered "lexical" } \\
\text { units (in a continuum of lexicality) } \\
\text { ALIGN-R(LEXP;PPH) } \\
\text { - indefinition about the superordinate category: analysis as a } \\
\text { recursive PW is rejected considering there is no word stress } \\
\text { reassignment; similarly to PPh or CG, considering that prosodic } \\
\text { compounds are not maximal projections (Ito and Mester. 2008) }\end{array}$ & $\begin{array}{l}\text { - limits of PWs ensure full } \\
\text { transparency of the morphological } \\
\text { units involved, which are plenty } \\
\text { productive }\end{array}$ \\
\hline
\end{tabular}




\begin{tabular}{|c|c|}
\hline \multicolumn{2}{|l|}{ ADJUNCTION } \\
\hline $\begin{array}{l}\text { ALIGN (PW;LEX) >> NONRECURSIVITY } \\
\text { - main word stress is reassigned resulting in one prominence } \\
\text { - affix is not prosodized as a PW since it is not considered a } \\
\text { "lexical" unit } \\
\text { - recursion of PWs has to be treated as a violable constraint } \\
\text { (Selkirk, 1996) }\end{array}$ & $\begin{array}{l}\text { - left edge of PW marks the salience } \\
\text { of the base, which allows us to } \\
\text { recognize the internal structure of } \\
\text { the word } \\
\text { - the meaning of the affixes may } \\
\text { vary subtly depending on the } \\
\text { product of the formation }\end{array}$ \\
\hline \multicolumn{2}{|l|}{ INCORPORATION } \\
\hline $\begin{array}{l}\text { ALIGN (ROOT;AFFIX) } \\
\text { - no special prosodic effects } \\
\text { - generalized alignment constraints operate only for concatenating } \\
\text { morphemes }\end{array}$ & $\begin{array}{l}\text { - synchronic status of affixation } \\
\text { depends exclusively on } \\
\text { morphosemantic transparency (no } \\
\text { prosodic clues) }\end{array}$ \\
\hline
\end{tabular}

\section{Final remarks}

This description confirms the assumption that prefixes are less coherent than suffixes in the world languages (Peperkamp, 1997), since they are subject to adjunction besides composition and incorporation. In addition, the analysis seeks to address jointly prosodic and morphological aspects involved in word formation in BP. Residual problems feed the continuity of this research, such as the requirement of levels to deal with cases of epenthesis and resyllabification of adjoined and compositional affixes as well as the need to survey possible acoustic indicators to confirm the presence of one or two stresses per word.

\section{References}

BERMÚDEZ-OTERO, Ricardo (2007) Morphological structure and phonological domains in Spanish denominal derivation. In: Fernando Martínez-Gil \& Sonia Colina (Eds.) Optimality-theoretic studies in Spanish phonology. Amsterdam: John Benjamins, p. 278-311.

BISOL, Leda (2004) Mattoso Câmara Jr. e a palavra prosódica. DELTA, v. 20 n. especial, São Paulo: EDUC, PUCSP, p. 59-70.

BOOIJ, Geert. (1996) Cliticization as a prosodic integration: the case of Dutch. The Linguistic Review 13:219-242.

COLLISCHONN, Gisela.; SCHWINDT, Luiz Carlos (2005) Considerações sobre a sequência /sC/ inicial em Português Brasileiro. Revista Lingua(gem), Macapá: ILAPEC, v. 3, p. 249-266.

ITO, Junko and MESTER, Armin (2009) The extended prosodic word. In Kabak, Baris, and Jaent Grijzenhout, eds., Phonological Domains: Universals and Derivations. The Hague, The Netherlands: Mouton de Gruyter, pp. 135194.

NESPOR, Marina and VOGEL, Irene (1986) Prosodic phonology. Dordrecht-Holland: Foris Publications.

PEPERKAMP, Sharon (1997) Prosodic words. HIL dissertation 34. The Hague: Holland Academic Graphics.

SCHWINDT, Luiz Carlos (2000) O prefixo no Português Brasileiro: análise morfofonológica. Doctoral Thesis. Porto Alegre, Pontifícia Universidade Católica do Rio Grande do Sul.

SELKIRK, Elisabeth (1996) The prosodic structure of function words. In: James L. Morgan and Katherine Demuth (eds.) Signal to syntax: bootstrapping from speech to grammar in early acquisition. Mahwah, NJ: Lawrence Erlbaum Associates. p. 187-213.

VIGÁRIO, Marina (2001) The prosodic word in European Portuguese. Doctoral Thesis. Lisboa, Faculdade de Letras.

VIGÁRIO, Marina (2011) Prosodic structure between the prosodic word and the phonological phrase: recursive nodes or an independent domain? The Linguistic Review 27. Walter de Gruyter. 